\title{
Taking Knowledge Seriously: Towards an International Political Economy Theory of Knowledge Governance
}

\author{
Blayne Haggart
}

International Political Economy (IPE) scholarship has traditionally focused its attention on issues of production, trade, and finance. The treatment of knowledge - particularly commodified knowledge-as a source and vector of power equal to or greater than that of finance or production is a key blind spot in our understanding of the global political economy. This chapter offers a framework, based on the work of Susan Strange, for considering the relationship between what she called the "knowledge structure" and the other key sources of political and economic power-security, production, and finance. Because Strange's structural framework is explicitly

This chapter is a modified and updated version of an article that originally appeared as "Incorporating the Study of Knowledge into the IPE Mainstream, or, When Does a Trade Agreement Stop Being a Trade Agreement?" Journal of Information Policy 7 (2017): 176-203.

B. Haggart $(\bowtie)$

Brock University, St. Catharines, ON, Canada

e-mail: bhaggart@brocku.ca

(C) The Author(s) 2019

B. Haggart et al. (eds.), Information, Technology and Control in a Changing World, International Political Economy Series, https://doi.org/10.1007/978-3-030-14540-8_2 
concerned with the relationship among these four factors, it offers a useful way for scholars to treat knowledge governance-including intellectual property (IP), internet governance, and data governance-as a significant influence on economic prosperity and societal well-being.

This chapter also proposes an articulation of Strange's knowledge structure that attempts to address her assertion that the effects of the knowledge structure were "unquantifiable" (1994, 119). It does so by disaggregating Strange's framework into two interrelated but analytically separable aspects - its regulatory aspect (the rules governing the creation, dissemination, and use of knowledge) and its knowledge-legitimation aspect (the processes by which certain knowledge is deemed legitimate or not). A focus on the regulatory aspect of the knowledge structure both reveals what knowledge is considered to be legitimate and allows us to investigate directly the key question of who benefits from particular expressions of knowledge-regulation, subjects that motivate the research discussed throughout this book. It also highlights the extent to which we are seeing the emergence of a newly dominant form of economic conflict, one centred not around free trade versus protectionism, but between what I call knowledge feudalism and digital statism.

This chapter is structured as follows. The first section defines what this chapter means by knowledge governance, emphasising its distinction between information and knowledge. This point is illustrated primarily with respect to IP and data. The second section presents the chapter's Strangean-derived theory of the knowledge structure. The third section uses an examination of the negotiations over the Trans-Pacific Partnership (TPP, now the Comprehensive and Progressive Agreement for TransPacific Partnership, CPTPP) and the United States-Mexico-Canada Agreement (USMCA) concluded in September 2018, to underscore the utility of a knowledge structure-based analysis, particularly to highlight aspects of such agreements that are often missed when knowledge governance issues are not emphasised. It also defines the key dimension of the debate over knowledge governance, namely between knowledge feudalism and digital statism. The final section offers some thoughts about how scholars can use this approach to study the rising importance of knowledge governance in other areas of the global political economy. 


\section{Structural Power, Knowledge, and the Knowledge Structure}

"Knowledge is power" is not a new saying. The control of knowledge has been central to human activity, whether it is religious knowledge in terms of how to get to heaven (Strange 1994, 123), scientific knowledge of how a steam engine works, or purloined knowledge used to compromise a rival country's president. The first step in understanding the role that knowledge plays in human society involves recognising the difference between knowledge and information. In their foundational work, The Social Construction of Reality: A Treatise in the Sociology of Knowledge (1966), Berger and Luckmann define knowledge as "the certainty that phenomena are real and that they possess specific characteristics" (1966, 14). Knowledge is an approximation of an underlying reality-of phenomena-that we can think of as information. Knowledge is created through social processes; it is socially constructed. Consequently, knowledge creation involves human agency and interpretation: it is always and necessarily a partial, intersubjective representation of information/phenomena. It need not be an accurate representation of information/"reality"-as in the case of "fake news"-but it can be. For example, data, while often thought of as pure information, is a form of knowledge. It is a partial representation of underlying phenomena whose collection (through the decision to make an observation) and definition are the product of human decisions. As the title of Gitelman's 2013 volume put it succinctly, "Raw data is an oxymoron": it is knowledge, not information.

While knowledge has always been politically, socially, and economically central to society, its relative importance has arguably changed over the past several decades. The case of IP is instructive. IP is the legal framework regulating the creation, use, and dissemination of commodified knowledge, be it creative works (copyrights), industrial processes (patents), or identifying marks (trademarks). ${ }^{1}$ It is a form of knowledge, not information, because it represents a commodified, partial apprehension of an underlying phenomenon. Copyright, for example, attributes the creation of a text to an individual author. In reality, of course, every text builds on

\footnotetext{
${ }^{1}$ These are the three primary types of intellectual property (IP); others include trade secrets and "neighbouring rights," which protect copyright-adjacent rights such as broadcasting.
} 
and incorporates already-existing texts, as the citations in this chapter attest. As Jessica Litman notes, the notion of the individual author is merely a useful "conceit" that allows us to give some order to the creation of knowledge (1990, 42).

For most of the past several hundred years, IP has been a relatively obscure backwater, of interest primarily to those industries and practitioners directly affected by it, such as publishers and pharmaceutical manufacturers. This is no longer the case. That the 2015 National Security Strategy of the United States elevated the protection and enforcement of IP law to a national security concern (Halbert 2016; Haggart and Jablonski 2017) demonstrates the extent to which IP is no longer a niche issue. IP, as well as data and internet governance, now lie at the very heart of the global order.

More specifically, "intangible assets" such as IP, but also "brand names, research and development, patents and other forms of abstract capital such as digital platforms and data flows" have overtaken "so-called fixed or tangible assets in the profitability and valuation of many leading corporations" (Bryan et al. 2017, 56), accounting for anywhere from 50 per cent to 84 per cent of the market value of the Standard and Poor's 500 index (Monga 2016; Ocean Tomo 2015). This change signals the importance of the control of data and IP, and the means by which these are created and disseminated, which very much includes the internet, as well as the arrival of a transformative moment in the global political economy (Bryan et al. 2017, 57).

Understanding how knowledge operates in the global political economy requires unpacking the links between knowledge and society. The framework developed by Strange offers a compelling and coherent theory of how knowledge fits within the wider political economy. Strange argued that the exercise of relational power-the ability to get someone to do something they would not otherwise do-was much less consequential than the exercise of structural power. She defined structural power as

the power to shape and determine the structures of the global political economy within which other states, their political institutions, their economic enterprises and (not least) their scientists and other professional people have to operate. This structural power ... means rather more than the power to set the agenda of discussion or to design ... the international regimes of rules and customs that are supposed to govern international economic relations. ... Structural power, in short, confers the power to decide how things 
shall be done, the power to shape frameworks within which states relate to each other, relate to people, or relate to corporate enterprises. (1994, 24-25)

Some forms of structural power are more important than others. Strange identifies four in particular, which she argues are most necessary to the survival of human communities. They are as follows:

- security - "the provision of security by one group for another. They may in the process acquire advantages in the production or consumption of wealth and special rights or privileges in that society" (May 1996, 178);

- production- "what is produced, by whom and for whom, and on what terms" (May 1996, 179);

- finance-the ability to control and deny access to credit, and thus to production and markets; and

- knowledge, which this chapter will discuss below.

In contrast to a Marxist approach, which prioritises production as the foundation of power, or realist International Relations, which emphasises physical security, Strange does not accord a priori importance to any single structure. Rather, each can be relatively more important in a given era or situation (May 1996, 178; see also Cox 1996). For example, Strange's empirical work on global finance (e.g., Strange 1986, 1998) argues that finance has been the key structure in the global economy since the 1980s (May 1996, 180-181). By not prioritising one structure over another, her structural-power framework is more sensitive to various fundamental changes in the global political economy than production- or securityfocused theories. Furthermore, she acknowledges that each structure is distinct yet interrelated. For example, in providing security, actors "may in the process acquire advantages in the production or consumption of wealth and special rights or privileges in that society" (May 1996, 178). The result is a framework that is historically based and alert to a multitude of areas from which substantial change might emerge.

It is also important to note that although Strange uses the language of "structures," human agency is a key component of her theory. Strange's framework focuses on the exercise of power and authority in the political economy, power being the ability to set (or have authority over) these structures. This authority is always exercised by actors, which can be both state and non-state actors. 


\section{Unpacking the Knowledge Structure}

Although Strange placed knowledge at the heart of her analysis of the sources of power in the global economy (alongside production, finance, and security), her elaboration of the knowledge structure itself is both the "most suggestive (and problematic)" of Strange's four structures (May 1996, 182). Strange herself argues, "Power derived from the knowledge structure is ... unquantifiable" (1994, 119), which would certainly seem to pose some small challenge to social scientists wishing to understand its effects. Thankfully, as this section will illustrate, this is not exactly the case: the knowledge structure is, in fact, capable of being analysed.

Strange defined the knowledge structure as determining "what knowledge is discovered, how it is stored, and who communicates it, by what means to whom and on what terms" (Strange 1994, 121). The key actors in the knowledge structure are "those who are acknowledged by society to be possessed of the 'right', desirable knowledge and engaged in the acquisition of more of it, and those entrusted with its storage, and on those controlling in any way the channels by which knowledge, or information, is communicated" $(1994,121)$.

In this definition, Strange identifies but conflates two related but distinct processes. The legitimation of knowledge involves deciding what is considered to be legitimate knowledge, and who is to be recognised as the purveyors or sources of this knowledge. This issue is separate from control over the communication (and, we could add, creation, dissemination, and use) of knowledge. Understanding what maintains and challenges ideologies - what is considered to be "the 'right', desirable knowledge" - is fundamentally a different task than understanding how knowledge (whatever form it may take) is created, disseminated, and used. Rendering Strange's knowledge structure concept useful as an analytical tool, therefore, requires disaggregating these two aspects.

\subsection{Knowledge-Legitimation}

Thankfully, these two categories are easily disaggregated, into what this chapter will refer to as the knowledge-legitimation and knowledge-regulation aspects of the knowledge structure. The first category, knowledgelegitimation, to use Strange's words, "comprehends what is believed (and the moral conclusions and principles derived from those beliefs)" and what is known (Strange 1994, 31-32). This is akin to the Berger and 
Luckmann definition of knowledge mentioned earlier, which sees it as a partial apprehension of underlying phenomena.

It is this knowledge-legitimation part of the knowledge structure that Strange seems to argue is "unquantifiable." While it is possible to see that epistemologies and ontologies have changed over time, identifying the source of power to create beliefs (Langley 2009, 130) would seem to present some serious, if not impossible, ${ }^{2}$ challenges, not least because of the socially constructed nature of knowledge itself. The knowledge-legitimation aspect of the knowledge structure also raises the question of its relationship to the rest of the global political economy. Strange argued that no structure, including the knowledge structure (specifically, its knowledge-legitimation aspect) has a fundamental primacy over any other. However, as Langley notes from a poststructuralist perspective, if socially constructed knowledge shapes how we approach the world, it must be given ontological primacy (Langley 2009). Tooze, like Langley, notes that while Strange recognises that power is constructed and maintained by belief systems and systems of meaning (e.g., language) and not simply by material means alone, her realist/positivist commitments prevented her from following this insight to its logical conclusion (Tooze 2000, 188-189). In short, she failed to place language and knowledge as necessarily prior to the other structures.

Scholars recognised this problematic aspect of Strange's knowledge structure early on. In grappling with this issue, May argues for a research agenda that focuses not only on

questions regarding what is known by whom, but [also] as importantly why certain truths are accepted as known, while others are not, and how this agenda of truth is set and contested within the knowledge structure. When we start to address these sorts of issues, we can start to fully recognise the interaction between the knowledge structure and the security, production, and finance structures. (emphasis in original) (1996, 185; see also Langley 2009, 132)

While Strange's commitments may have prevented her from giving “ontological primacy to knowledge" (Langley 2009, 131), it is possible to incorporate Langley's, May's, and Berger and Luckmann's insights on the social construction of reality into Strange's model without sacrificing its utility in empirically analysing the effects of the knowledge structure. Acknowledging that the social construction of reality and knowledge

\footnotetext{
${ }^{2}$ For a classic example of how paradigm/belief shifts have been studied in political science, see Hall (1993).
} 
necessarily requires recognising the knowledge-legitimation structure's (or knowledge-as-belief) primacy over the other structures, since knowledge shapes the terms on which we engage with the world. At the same time, Strange's posited connections between the knowledge structure and the other structures suggest that power related to knowledge-legitimation can be influenced by events in the other structures.

\subsection{Knowledge-Regulation}

The second part of the knowledge structure, the knowledge-regulation category, is more amenable to direct analysis. Knowledge must be communicated to others in order to be useful. ${ }^{3}$ This happens via "channels by which beliefs, ideas, and knowledge are communicated-including some people [and ideas, one might add] and excluding others" (Strange 1994, 119). These are subject to political contestation and regulation. Thus, what form they take and who they favour can tell us a great deal about power in the knowledge structure.

This part of the knowledge structure consists of the formal and informal rules governing the creation, dissemination, and use of knowledge, and the networks-human, institutional, technological-involved in knowledge creation, dissemination, and use. Examples of this form of structural power include IP laws, data governance (decisions related to its collection and use), and internet governance. Many other examples could be added to this list. This regulatory part of the knowledge structure continues to be under-examined by International Relations and IPE scholars, even though we live in a time of "unprecedented structural change" within the global capitalist economy, facilitated, and stimulated by "unprecedented transnational communication capacities" (Comor 1994, 1).

Understanding this second part of the knowledge structure is crucial for three reasons. First, the fact that knowledge must be communicated to exist in any real form as knowledge means that studying the communication of knowledge-what is communicated, by whom, and howcan render visible dominant or conflicting ontologies and epistemologies: the supposedly "unquantifiable" becomes quantifiable. If we assume that which is deemed to be socially valuable is communicated, examining the regulatory characteristics of the knowledge structure can reveal

\footnotetext{
${ }^{3}$ This formulation ignores knowledge of the world that, in Berger and Luckmann's (1966) sense of the word, individuals share with no one.
} 
what society believes to be valuable knowledge, and the key players in this area. For example, the distinction made by copyright law between otherwise identical digital copies of "legitimate" and "pirated" movies suggests that the arbiter of legitimacy in the cultural sphere are marketbased actors, namely those movie studios that control economically valuable copyrights.

We can make a similar argument about data. Data (personal or otherwise) is what political economist Karl Polanyi would call a "fictitious commodity" (Polanyi 2001), a partial representation of human activity or naturally existing phenomena collected for some purpose. For example, a doctor might record your heartbeat to assess your health, while a fitness device might collect yours and others' heartbeats as data to be sold, perhaps to an insurance company. Failure to recognise that data is a form of partial, commodified knowledge governed by rules and norms can lead to perverse policy outcomes, perpetuating existing societal injustices and inequalities (Haggart 2018).

The analytical separation between the knowledge-legitimation and knowledge-regulation categories proposed here does not imply a functional separation; it merely allows for a wider variety of questions to be asked and investigated in a more analytically precise manner. Communication technologies and knowledge-regulation generally are co-constitutive with the knowledge-legitimation side of the knowledge structure. For instance, Comor (2001) argues that the increasingly commercial nature of the internet-shaped by regulation driven by key U.S. economic and political interests (knowledge-regulation)—would make it more likely to produce a global commercial society than the global civil society dreamed of by internet optimists (knowledge-legitimation). More recently, Powers and Jablonski (2015) argue that U.S. political ideology and commercial interests shape the U.S. Administration's "Internet Freedom" agenda. The effect in both cases is to promote regulations, laws, treaties, and technological standards that reflect and reinforce a specific view of what information should flow freely (political) and what should be restricted (commercialised), as well as ubiquitous electronic surveillance that represents a sharp departure from the privacy standards of the international postal (snail mail) regime. In short, regulation reflects ideology, and vice versa. Understand one and you are on your way to understanding the other.

Second, as has already been noted, access to and control over knowledge is increasingly becoming a direct vector for the exercise of power. The ris- 
ing use of IP laws to capture value within global production chains - which implies a relatively less important role for labour and physical productionoffers a clear example of this new reality (Dedrick et al. 2010). The increasingly ubiquitous state and commercial use of surveillance technologies and the datafication of everything demonstrates the same point (Gitelman 2013; Mayer-Schönberger and Cukier 2013; West 2017; Zuboff 2015).

Third, the question of whether the digital revolution is ushering in a fundamental change in our basic conceptions of knowledge and social organisation remains open. Strange, who died in 1998, argued that the digital revolution was not that revolutionary, because we have not seen a switch in what is considered authoritative knowledge (i.e., belief systems) as dramatic of that from religious to scientific authority during the Enlightenment (Strange 1994, 127-129). The continued propertisation of knowledge via IP and data has the potential to move us into a world of secular, corporatised knowledge, in which the legitimacy of a specific piece of information (i.e., whether it is "right" to use it) is determined not by an appeal to scientific truth, but to whether the knowledge has the appropriate ownership pedigree. Access to life-saving medicines governed/restricted by patents is an obvious example of this tendency.

Even if we are not witnessing an epochal change in the knowledgelegitimation part of the knowledge structure, it still makes sense to focus more on the knowledge structure, as even regulatory changes can have significant effects on everyday life.

\section{Operationalising Strange: The Knowledge Structure in the Global Political Economy}

The Strangean structural-power framework discussed above necessarily involves historical analysis. Highly protectionist IP rights, for example, did not just become important within trade agreements because of some law of nature or as the result of some inevitable feature of capitalism. Neither is there anything "natural" about the internet's decentralised structure, or its bias towards a particular conception of "internet freedom." Rather, knowledge structures emerge through historically contingent actions of state and non-state actors. By tracing how knowledge-governance regulations (knowledge-regulation) have changed over time, we can not only discern the key players exerting structural power, and whose interests 
have been served by these changes, but we can also better understand changes in what forms of knowledge are considered to be legitimate (knowledge-legitimation).

For Strange, as has already been noted, power and authority "are conferred on those occupying key decision-making positions in the knowledge structure" $(1994,121)$. This approach suggests three questions that we can use to guide a substantive research agenda in the knowledge structure:

1. On the knowledge-legitimation side, quoting and paraphrasing May (1996, 185): why are certain "truths" accepted as known, while others are not, and how is this agenda of "truth" set and contested within the knowledge structure?

2. On the regulatory side, from Strange, how, to whom, and on what terms is knowledge created, communicated, and used?

3. How do changes in the knowledge structure affect the exercise of power and outcomes in other parts of the political economy?

To illustrate the importance of these questions, the following section uses the negotiation of the (CP)TPP to explore why IP and cross-border data flows are included in free trade agreements; who the dominant actors are exerting structural power in this area; and the implications of this exertion of structural power on the wider society.

This analysis highlights how the emergence of highly protectionist IP rights and an embrace of the free flow of (commodified) data across borders has come to be seen as a natural part of the international trade regime, even though the economics of intangibles such as IP and data is not the same as the economics of tangible goods. Specifically, these IP and data provisions reflect the exercise of structural power by key state and nonstate actors promoting their conception of their own self-interest. The result has been the transformation of the global political economy from one based on production and finance to one dominated by knowledge.

\subsection{The Curious Cases of Intellectual Property and Data in International Trade Agreements}

Since the 1990s, IP rights have been a central feature of almost every major international trade agreement, to the extent that they are now normally thought of as being part of the international trade agenda. More 
recently, cross-border data flows have also been accepted unquestioningly into these agreements. If one takes a small step back, however, the issues raised by their inclusion-in other words, their legitimation as a commodified form of "tradeable goods" - becomes readily apparent. Following the establishment of the Bretton Woods system, specifically the General Agreement on Tariffs and Trade (GATT) after World War II, countries have used international trade agreements to liberalise trade. This pursuit of "free trade" was legitimised through appeals to David Ricardo's famous 1817 theory of comparative advantage, which holds that-under certain circumstances-even countries that are absolutely worse at producing goods than their partners can gain from trade. It is not too much to say that the modern economic argument in favour of trade agreements rests almost exclusively on the shoulders of, and draws political and social legitimacy from, the theory of comparative advantage.

The major problem for including data flows and IP in trade agreements is that the theory of comparative advantage does not apply to intangibles such as IP and data. While the lower tariff and non-tariff barriers-the nominal goal of most liberal trade agreements-are supposed to encourage trade, stronger IP effectively acts as a barrier to the exchange and use of knowledge and the goods (such as books, journals, and digital files) that store this knowledge. While free trade can potentially result in win-win situations, stronger IP benefits IP owners and states that host these owners (primarily the United States), while disadvantaging non-IP owners, who must pay to access innovation-creating knowledge and hope that the terms are not too stringent. However, because these economic agreements tend to be seen through a trade lens, protectionist tendencies of IP are often ignored or downplayed. IP's inclusion in trade agreements (the "free" in front of trade is sometimes silent but always implicit) means that strong IP protection has been effectively legitimised by the doctrine of comparative advantage, despite comparative advantage having no relevance whatsoever to it. In this sense, IP can be thought of as a "free trade free-rider."

Data functions in a similar way. As with IP, the proprietary control of data allows for the establishment of network effects, potentially leading to anti-competitive effects (Haggart 2018; Srnicek 2017). The concern of control then becomes a key issue, affecting everything from individual property rights to the ability to deliver public services. On property rights, always-connected Internet of Things devices not only deliver data (to be analysed and quantified) back to the home company, they allow the company to treat the purchased object as a service that only works if it remains 
connected, and the company can effectively brick it at any moment (see Tusikov in this volume). In much the same way, as private data companies increasingly establish themselves in markets such as rental housing, they appropriate and make proprietary data essential to the planning and delivery of government services; as Scassa notes in the case of Airbnb, this effectively creates a dependency relationship between city governments and Airbnb (Scassa 2017). Placed in a global context, with markets in areas of search and social networks dominated by U.S.-based monopolies, calls for free cross-border data flows can be seen as a problematic push to maintain U.S. dominance over data-based businesses. This dominance emerges because already-established U.S. giants can use free cross-border data provisions in international trade agreements to expand into other countries without facing any restrictions on their activities and dominate any local players. Such provisions can be problematic because they mean that individuals' data can be transferred to countries where they may face, for example, different privacy rules. ${ }^{4}$

\subsubsection{Knowledge Feudalism}

Such provisions enact a form of what, following Drahos and Braithwaite (2002), we can call knowledge feudalism, since the combination of proprietary knowledge and free cross-border knowledge flows lock IP- and datapoor countries into dependent relationships with IP- and data-rich countries and companies. In contrast, smaller countries and emerging companies will (or should) tend to pursue policies that enable balanced (user-friendly) IP provisions, greater cooperation related to data sharing and an openness to data-localisation provisions in trade agreements. Taken together, such policies would work to negate the advantages enjoyed by dominant, often-monopolistic knowledge-based companies.

Commodified knowledge in the form of IP and data emerged from historical processes deeply rooted in capitalism, Enlightenment individualism, and the emergence of the nation-state, which serves as the enforcer of IP rights and historically has pursued data collection as a means of selfidentity and security. ${ }^{5}$ In terms of our immediate questions related to the introduction of IP and data-flow regulations into trade agreements and

\footnotetext{
${ }^{4}$ This assertion actually understates the significance of this situation, since data is an increasingly central component of all business activities.

${ }^{5}$ On the historical emergence of IP, see Sherman and Bently (1999); on the state's relationship with data and statistics, see Scott (1998).
} 
their benefits, we can begin our account in the 1960s for data flows and the 1970s for IP.

With respect to IP rights, both the presence of IP in trade agreements and their highly protectionist/knowledge-feudalist orientation emerged out of the domestic politics of the United States. In the 1970s, pharmaceutical companies, manufacturers whose business model was based on exploiting and protecting their patents, lobbied the U.S. government to pursue ever-stronger international IP protection (Drahos and Braithwaite 2002; Sell 2003). As Sell (2003) and Drahos and Braithwaite (2002) document extensively, they were resoundingly successful in convincing a government preoccupied with the potential loss of its economic hegemony to the rising "Asian Tigers," particularly Japan, to pursue stronger IP rights. Over the subsequent two decades, IP-based industries and the U.S. government, particularly the Office of the United States Trade Representative, worked together - with one side sometimes pulling or pushing the otherto make strong, protectionist IP rights an essential part of the U.S. trade agenda.

A similar story can be told for the inclusion of protection for free crossborder data flows in trade agreements. In this case, we can look to the famous roots of the internet itself in the 1960s as a U.S. military project designed to keep the country's command-and-control structure functioning in a decentralised manner in the event of a nuclear war. As Powers and Jablonski (2015) document, the decision in the 1990s to commercialise this nascent "information superhighway" led to the emergence of a vibrant commercial internet sector, whose economic lifeblood quickly became the data produced by its customers and captured through increasingly ubiquitous surveillance. As the birthplace of the internet and with a head start on the rest of the world, the United States produced the world's (with the primary exception of China) leading, and monopolistic, internet companies: Google and Facebook as the new kids on the block, joined by the previous generation's duopolists, Microsoft and Apple. Srnicek (2017) tells an alternate but complementary story, arguing that the push towards the increasing commodification of data was largely the result of the 2008 Global Financial Crisis, as companies increasingly turned to the use of data in order to maintain the economic returns to which they had become accustomed. This policy, while seemingly in keeping with the ideals of free trade, has the effect of allowing U.S.-based data companies such as Google and Facebook to use network effects to stifle potential competition in other countries (Haggart and Jablonski 2017; Powers and Jablonski 2015). 


\subsubsection{Digital Statism}

Although knowledge feudalism is ascendant, it is not an inevitability set in stone. Rather, it is the socially constructed outcome of a confluence of social, political, and economic factors, largely centred on the United States. In response to this knowledge-feudalist strategy, we are witnessing in many corners the emergence of state-centred economic strategies emphasising national competitiveness and varying degrees of openness to less-restrictive IP rules, as well as an openness to considering limits on unfettered cross-border data flows. This chapter refers to this constellation of policies as digital statism, and can also perhaps be thought of as a form of digital economic nationalism. For example, in the area of machine learning (or "artificial intelligence"), states are being encouraged to pick winners in an attempt to create their own national champions to counter the U.S. giants. Sovereign patent funds, in which the state controls and licenses strategic patents to its favoured (domestic) industries, are attracting interest, as are public data trusts, which would control data generated by the public and put to socially approved uses (Fitzgerald 2017; Srnicek 2017). Cries for substantial regulatory reform of the giant internet platforms are becoming more common, particularly in regards to the need for governmental regulation (see, e.g., Srnicek 2017; Noble 2018; Schneier 2015). Many governments have embraced or are considering rules requiring that data generated in their territories remain in their territories, although they remain controversial (World Trade Organisation 2018, 143-144).

Such policies, rather than being traditional forms of protectionism, are at least partly a reaction to the particular nature of an economy based on the control of knowledge, and the monopolistic-style returns that can accrue to the company or country that controls economically valuable knowledge and the means of communication.

The global scale of the internet means that these issues, and the importance of telecommunications policy, assume a global importance. At the heart of this system currently sits the United States, which claims a special place as the guarantor of the internet. Just as the 2015 U.S. National Security Strategy sets out a national-interest position on IP, so too does it for internet governance: "As the birthplace of the Internet, the United States has a special responsibility to lead a networked world" (White House 2015). This leadership, the report continues, involves upholding "the long-standing norms of international behavior." The report lists these as including "protection of intellectual property, online freedom, and respect for civilian infrastructure" (White House 2015), suggesting that these 
issues - internet governance, IP and data governance-should be seen as a unified form of knowledge governance, and the U.S. approach as a form of knowledge feudalism. As currently configured, global internet governance largely reflects U.S. commercial and social priorities, privileging political speech and protecting the interests of U.S.-based IP owners and internet data companies like Google (Powers and Jablonski 2015). These views are also reflected in the trade agreements to which this chapter now turns.

\subsection{Trade and the (CP)TPP: When Is a Trade Agreement Not a Trade Agreement?}

The TPP was negotiated largely in secret among the United States, Japan, and ten other Asia-Pacific countries beginning in $2008 .{ }^{6}$ The agreement was signed in February 2016. Following the withdrawal of the United States in January 2017, the 11 remaining members negotiated a modified version of the TPP, the CPTPP, which was signed on March 8, 2018. Both the negotiation of the TPP and its quasi-successor agreement, the CPTPP, hold significant lessons for our understanding of global economic governance, especially as it relates to IP and knowledge governance. Most significantly for our purposes, in the absence of U.S. pressure the TPP's IP provisions were significantly watered down in the CPTPP, even as its datagovernance provisions remained.

The negotiations for the "original" TPP, for many reasons, faced considerable and virulent opposition. In terms of motivations, proponents have focused on the TPP's role as a geopolitical move to counter China in the Asia-Pacific (e.g., Solis 2015) and the benefits that would accrue to members in a "free trade" area encompassing " 12 nations on four continents" (e.g., Daley 2015). Its 30 chapters cover trade in goods and services, as well as investment dispute settlement, electronic commerce (i.e., internet governance), and IP rights (Office of the United States Trade Representative 2015). The dominant framing of the agreement was as a "free trade" agreement (e.g., Curry 2016).

The problems with the framing of the TPP as a "free trade" or even as a "trade" agreement are nicely illustrated by Nobel Prize-winning economist Paul Krugman's intellectual journey with respect to the TPP. On December 12, 2013, Krugman, the most prominent economist of his

\footnotetext{
${ }^{6}$ By 2016, TPP membership consisted of Australia, Brunei, Canada, Chile, Japan, Malaysia, Mexico, New Zealand, Peru, Singapore, Vietnam, and the United States.
} 
generation, remarked on his New York Times blog that he was "having a hard time figuring out why this deal is especially important." Krugman, an international trade economist by training, argued that the TPP was unlikely to have any significant effect because "most conventional barriers to trade-tariffs, import quotas, and so on-are already quite low" (Krugman 2013a). After over 60 years of continuous multilateral trade negotiations, the "battle" to liberalise the global trading regime "has been decisively won," with "import tariffs and other restrictions ... reduced to the lowest levels the world has ever seen" (Rodrik 2011, 252). According to the World Bank, the average all-country most-favoured-nation applied tariff rate in 2010 was 8.1 per cent. This was down from 26.3 per cent in 1986. In high-income Organisation for Economic Co-operation and Development countries, the rate was even lower: 2.8 per cent in 2010 (Rodrik 2011, 252). Rodrik cites research arguing that eliminating all remaining tariffs everywhere would raise world economic activity by only one-third of 1 per cent $(2011,252)$.

However, as Krugman (2013b) realised only two days later and has since continued to remark (Krugman 2015a, b, c), the current generation of "trade" agreements are no longer focused mainly, or even primarily, on traditional trade issues and should not be analysed as if they do. Rather, IP and investor-state dispute settlement have emerged as the key areas of concern with the agreement, alongside the negotiations' all-enveloping secrecy. To this, we could add the TPP's e-commerce chapter, which guarantees cross-border data flows and prohibits the requirement of local data storage as a condition of doing business in a TPP country (Geist 2017). This guarantee fits with U.S. objectives to ensure that the internet's "pipes" remain open to the free flow of data, including U.S. IP, while potentially allowing U.S. security agencies legal access to data coming into or going out of the United States.

The withdrawal of the United States from the TPP led the remaining 11 states to renegotiate the agreement. As one would expect from IP-importing states, and in line with a digital statist framework, in the move from the TPP to the CPTPP, states, led by Canada (Geist 2017), agreed to suspend the original TPP obligations as they related to a number of IP factors:

- Obligations related to patent-term adjustment and patent-term restoration, data protection for small-molecule drugs and biologics, and certain provisions on patentable subject matter; 
- An extension to the term of copyright and related rights, a provision on national treatment related to payments on copyright and related rights, and provisions related to digital locks and rights-management information, two key areas of digital-copyright law; and

- New obligations related to the liability of Internet Service Providers for the actions of their users, and related to enforcement in respect of encrypted program-carrying satellite and cable signals (Government of Canada 2018).

The provisions related to the free flow of data (especially CPTPP Article 14.4), however, remained, which is inconsistent with an anti-knowledge feudalist, digital statist approach and requires explanation.

\subsection{A Strangean Analysis of the TPP and CPTPP}

That non-trade issues are increasingly important in such agreements presents problems for our understanding of the meaning of such agreements and highlights the extent to which production is increasingly intertwined with knowledge governance. First, it calls into question the agreements' legitimacy, since they are not based on Ricardo's theory of comparative advantage. Second, and related, approaching these agreements as if they are primarily about trade obscures their potentially more-important longerterm role in setting global (non-trade) standards for IP and data.

As stated above, a knowledge-structure analysis of agreements like the TPP or CPTPP focuses one's attention on three key questions:

1. What type of knowledge is defined as important, and how this definition is set and contested within the knowledge structure-in this case, the TPP?

2. How do regulatory measures define and shape the creation, communication, and use of knowledge?

3. Who benefits from these rules and definitions?

The first two questions are intertwined, since regulations constitute particular definitions of knowledge. The IP chapter of the TPP can be seen as a continuation of the United States' decades-long push for ever-moreprotectionist IP laws, bilateral trade agreements with countries such as Australia and Jordan, as well as the plurilateral and ill-fated AntiCounterfeiting Trade Agreement (Flynn et al. 2012). 
The TPP looks quite different if one starts from the perspective of the knowledge structure, taking seriously its knowledge-regulation components, rather than starting from the assumption that this "trade" agreement must primarily be about production and trade. Seen from this perspective, it appears as an attempt to lock the TPP members into a knowledge-feudalist framework. As Weatherall $(2016,2)$ notes, the TPP's IP chapter would have actually "facilitate[d] the erection of barriers to [the] free movement of goods and the provision of services across borders." For example, Weatherall argues that "the IP chapter is perhaps the only chapter in the TPP which [would have made] it easier to stop goods at the border because the border measures ... which [would have] allow[ed] for detention of alleged infringements at the border, are broadly written" $(2016,3)$. While this finding should not come as a surprise, as it is in keeping with the reality, noted above, that protectionist IP almost necessarily acts as a barrier to exchange, it is obscured in discourses that focus on tariffs and treat IP in trade agreements as an issue that does not require extensive economic evaluation.

The protectionist, knowledge-feudalist aspects of the TPP's IP chapter could also be observed in its requirement that member countries extend the term of copyright protection to life of the author plus 70 years (Canada's, for example, was life plus 50 before the TPP talks; the 2018 USMCA that as of this writing is slated to replace the North American Free Trade Agreement would raise it to life plus 70). This change is an example of unabashed protectionism. Copyright is supposed to encourage the creation of creative works by providing creators with the exclusive right, subject to some exceptions, to exploit their work. This protection comes at the cost of restricting future creativity: all new knowledge builds upon existing knowledge, so placing restrictions on who is allowed to access a work necessarily affects future creativity and the flow of knowledge. Extending the term of protection by 20 more years after the creator's death, in Canada's case, moreover, will not incentivise the creation of any more works: most people can barely plan out their lives five years in advance, let alone 70 years after their death. Beyond this change, the chapter also included a ban on the circumvention of digital rights management tools, criminal enforcement of copyright laws, and a de facto notice-andtakedown regime for Internet Service Providers wishing to avoid liability for their customers' actions (Malcolm 2015; Geist 2015a, b), policies that would have served to strengthen member countries' IP regimes. 
The TPP's e-commerce chapter's bias, meanwhile, was towards facilitating unfettered cross-border data flows. For example, paragraph 3 of Article 14.11 is a general prohibition on data localisation, and is worded in such a way to make it difficult for governments to require that data be stored locally, and not moved to another country where it would be covered by different data-protection frameworks (Kilic and Israel 2015, 3-4). This restriction raises issues around governments' ability to regulate on behalf of the privacy needs of its citizens, as citizens' data may be transferred to jurisdictions with lower privacy requirements. However, far from being contradictory, the two chapters are in fact complementary, in that the TPP's knowledge-related chapters privilege open networks over which well-protected (U.S.) IP can flow into other countries, with cross-border data flows subject to few local rules.

As this brief analysis suggests, the TPP privileged those actors that control economically valuable data and IP, and the means of distributing knowledge. The United States and U.S.-based industries were able to influence the rules towards knowledge-feudalist ends. While standard freetrade orthodoxy suggests that there is at least the possibility that "free trade" agreements (i.e., ones that lower tariff and non-tariff barriers) can lead to benefits for all parties, the knowledge-protectionist nature of the TPP would have made such a happy ending unlikely. Because it takes knowledge to create knowledge, knowledge-protectionist agreements almost necessarily benefit those who currently control existing commodified knowledge. Following this logic, the TPP can be seen as an agreement that was designed to create a global, knowledge-feudalist economic regime centred on the control and regulation of knowledge, in which current IP owners are well positioned to exact tribute from knowledge users (Balsillie 2016; see also Drahos and Braithwaite 2002). It would have reinforced global value chains in which production can be outsourced from the Global North to the Global South with the head companies in the Global North (such as Apple) able to maintain control over a large share of the value created through its control of IP. Strong IP protection in trade agreements effectively acts as rent-seeking, extracting revenue from foreign markets on behalf of Global North-based (primarily U.S.) IP owners. Including the free flow of data in these agreements is similarly designed to maintain the advantage of the global (U.S.) data giants. In terms of who would have benefitted, then, the United States, copyright and patent-based industries, and online technology and telecommunications companies like Google would have been the primary beneficiaries of agreements like the TPP. 
The TPP represented a concerted effort by the United States to exert structural power, not only in the sense of setting the regulations of global market for knowledge, but also with respect to the knowledge structure's knowledge-legitimation aspect, to convince other countries that the U.S. position favouring protection over dissemination is morally superior to those that emphasise the need and right to share and access knowledge and culture (Haggart and Jablonski 2017). If this analysis is correct, treating trade agreements as being primarily about the cross-border movement of physical goods is missing the extent to, and the means by, which the knowledge structure is becoming increasingly dominant as a means to power in the global political economy.

One puzzle remains. If the CPTPP's IP provisions rejected the knowledge-feudalist approach to IP, why did the CPTPP member states not change the TPP's provisions in favour of free cross-border data flows? The answer, in this case, comes back to the agency of the actors involved. As already noted, Canada led the charge to strike the TPP's IP provisions from the CPTPP. This move was largely the result of a concerted lobbying campaign by the Canadian tech community, particularly former BlackBerry CEO Jim Balsillie and his associated Council of Canadian Innovators. They, as well as the Waterloo-based think tank, Centre for International Governance Innovation (CIGI), laid the intellectual and political groundwork to convince the Canadian government to give IP a higher priority in the negotiations and to pursue a less-protectionist, less knowledge-feudalist IP policy. ${ }^{7}$ When it comes to data flows, however, governments remain, as of November 2018, behind the learning curve. The March 2018 FacebookCambridge Analytica revelations have led to a renewed appreciation of how Facebook had been engaging in ethically and legally questionable behaviour with its users' data in ways that may have contributed to the 2016 election of U.S. President Donald Trump and the Brexit vote in the United Kingdom. More generally, these events have served as a wake-up call as to the political and economic importance of data. They came, however, too late to influence the CPTPP. That said, it would be surprising if the next round of data-related trade talks were not affected by these revelations.

The changes in the CPTPP suggest an evolving but still limited understanding by the remaining countries of what it means to be in a knowledgebased economy, as the CPTPP countries dialled back the IP requirements while keeping the prohibition on data localisation. In other words, they were not yet acting fully as digital statists. This limited understanding

\footnotetext{
${ }^{7}$ Disclosure: The author has written several papers for CIGI.
} 
was confirmed by the September 30,2018, conclusion of talks between Canada and the United States to replace the North American Free Trade Agreement with a USMCA whose IP and data provisions largely replicate those of the TPP that the United States had rejected (Geist 2018a), including the 20-year copyright term extension and an even stricter datalocalisation prohibition (Geist 2018b). Canadian willingness to give in on these issues demonstrates the United States' strong relational power over Canada (the ability to get one actor to do something they would not otherwise do), as well as the Canadian calculation that these "new economy" issues were not worth going to the mat to defend.

Nonetheless, states are becoming ever-more aware of the importance of IP rights to their economic prosperity, and how stronger IP rights tend to disadvantage IP importers (i.e., most non-U.S. and non-European countries). In contrast to IP, the effects of data commodification remain relatively understudied and poorly understood by policymakers. Given the monopoly position of U.S. data-driven corporations, such as Google, in the nonChinese part of the global economy, these rules will contribute to the continued structural and relational power of the U.S. state and its data-driven firms.

\section{Conclusion}

Back when control over production was seen as a key determinant of state strength, it was often asserted that "What's good for General Motors is good for America." Now, in terms of the relative importance of the four sites of structural power, it is control over knowledge, not production, that has taken centre stage, a finding that is easily missed when one, for example, sees agreements like the (CP)TPP through a trade lens and not a knowledge lens. The choice of lenses can be consequential. As this chapter's analysis of the TPP and USMCA strongly suggests, adopting a trade lens as opposed to a knowledge lens leads governments to underestimate the far-reaching importance of knowledge-governance rules to the underlying structure of the entire economy.

A Strangean analysis has much to offer scholars who are already active on knowledge-governance issues. Its focus on foundational power structures allows us to highlight the inherently political, contestable nature of seemingly "natural" and "fixed" systems like copyright and the internet itself, while placing these issues within a wider political and social context. ${ }^{8}$

\footnotetext{
${ }^{8}$ In this, IPE overlaps with Critical Communication Studies, a relatively small subfield within Communication Studies.
} 
By focusing our attention on knowledge as a vector of power, on the interplay of state and non-state actors, and the connections amongst key structures in the global political economy, Strange's conceptualisation of structural power offers us a coherent way to understand these changes and their implications.

As scholars, we would not consider our students to have received a complete education if they graduated without at least some understanding of international security, global finance, and global production. As the examples of the TPP and CPTPP suggest, the time has come to add the global regulation of knowledge to this list. Clarifying Strange's conception of the knowledge structure offers a necessary first step towards setting a twenty-first-century pedagogical and research agenda that will allow a more complete answer to the fundamental questions of the global political economy: Who governs? And who benefits?

\section{REFERENCES}

Balsillie, Jim. 2016. For Canadian Innovators, Will TPP Mean Protection-Or Colonialism? Globe and Mail, January 30. http://www.theglobeandmail.com/ report-on-business/rob-commentary/for-canadian-innovators-will-tpp-meanprotection-or-colonialism/article28462854/.

Berger, Peter L., and Thomas Luckmann. 1966. The Social Construction of Reality: A Treatise in the Sociology of Knowledge. London: Penguin.

Bryan, Dick, Michael Rafferty, and Duncan Wiggin. 2017. Capital Unchained: Finance, Intangible Assets and the Double Life of Capital in the Offshore World. Review of International Political Economy 24 (1): 56-86. https://doi. org/10.1080/09692290.2016.1262446.

Comor, Edward A. 1994. Introduction: The Global Political Economy of Communication and IPE. In The Global Political Economy of Communication, ed. Edward A. Comor, 1-18. London: St. Martin's Press.

- 2001. The Role of Communication in Global Civil Society. International Studies Quarterly 45 (3): 389-408. http://www.jstor.org/stable/3096084.

Cox, Robert W. 1996. 'Take Six Eggs': Theory, Finance, and the Real Economy in the Work of Susan Strange. In Approaches to World Order, ed. Robert W. Cox and Timothy J. Sinclair, 174-188. Cambridge: Cambridge University Press.

Curry, Bill. 2016. The ABCs of TPP. Globe and Mail, January 25. http://www. theglobeandmail.com/report-on-business/international-business/what-istpp-understanding-the-new-pacific-tradedeal/article26648948/.

Daley, William M. 2015. Free Trade Is Not the Enemy. New York Times, May 19. Accessed September 3, 2018. http://www.nytimes.com/2015/05/19/opinion/ free-trade-is-not-the-enemy.html. 
Dedrick, Jason, Kenneth L. Kraemer, and Greg Linden. 2010. Who Profits from Innovation in Global Value Chains? A Study of the iPod and Notebook PCs. Industrial and Corporate Change 19 (1): 81-116. https://doi.org/10.1093/ icc/dtp032.

Drahos, Peter, and John Braithwaite. 2002. Information Feudalism: Who Owns the Knowledge Economy? London: Earthscan Publications Ltd.

Fitzgerald, Oonagh. 2017. Understanding the Promise and Peril of Sovereign Patent Funds. Centre for International Governance Innovation Policy Brief No. 102 (April). https://www.cigionline.org/sites/default/files/documents/ Policy\%20Brief\%20No.102web_0.pdf.

Flynn, Sean M., Brook Baker, Margot Kaminski, and Jimmy Koo. 2012. The US Proposal for an Intellectual Property Chapter in the Trans-Pacific Partnership Agreement. American University Law Review 28 (1): 105-205. http:// digitalcommons.wcl.american.edu/auilr/vol28/iss $1 / 5 /$.

Geist, Michael. 2015a. Why the TPP Creates a Backdoor Copyright Takedown System in Canada. Michaelgeist.ca. Accessed October 13, 2015. http://www. michaelgeist.ca/2015/10/why-the-tpp-creates-a-backdoor-copyright-takedown-system-in-canada/.

- 2015b. Canada Caves on Copyright in TPP: Commits to Longer Term, Urge ISPs to Block Content. Michaelgeist.ca. Accessed October 9, 2015. http://www.michaelgeist.ca/2015/10/canada-caves-on-copyright-in-tppcommits-to-longer-term-urge-isps-to-block-content/.

- 2017. Canada Successfully Stands Up for Balanced IP and Canadian Culture in TPP Deal. Michaelgeist.ca. Accessed January 23, 2017. http:// www.michaelgeist.ca/2018/01/canada-successfully-stands-balanced-ipcanadian-culture-tpp-deal/.

- 2018a. From Copyright Term to Super Bowl Commercials: Breaking Down the Digital NAFTA Deal. Michaelgeist.ca. Accessed October 1, 2018. http://www.michaelgeist.ca/2018/10/from-copyright-term-to-super-bowlcommercials-breaking-down-the-digital-nafta-deal/.

- 2018b. How Canada Surrendered Policy Flexibility for Data Localisation Rules in the USMCA. Michaelgeist.ca. Accessed October 10, 2018. http:// www.michaelgeist.ca/2018/10/how-canada-surrendered-policy-flexibilityfor-data-localization-rules-in-the-usmca/.

Gitelman, Lisa, ed. 2013. Raw Data Is an Oxymoron. Cambridge, MA: MIT Press. Government of Canada, Global Affairs Canada. 2018. What Does the CPTPP Mean for Intellectual Property? Accessed January 30, 2018. http://international.gc.ca/trade-commerce/trade-agreements-accords-commerciaux/agracc/cptpp-ptpgp/sectors-secteurs/ip-pi.aspx?lang=eng.

Haggart, Blayne. 2018. The Government's Role in Constructing the DataDriven Economy. Centre for International Governance Innovation, March 5. https://www.cigionline.org/articles/governments-role-constructing-datadriven-economy. 
Haggart, Blayne, and Michael Jablonski. 2017. Contradictory Hypocrisy or Complementary Policies? The Internet Freedom Initiative, US Copyright Maximalism and the Exercise of US Structural Power in the Digital Age. The Information Society 33 (3): 103-118. https://doi.org/10.1080/01972243.2 017.1294128 .

Halbert, Debora. 2016. Intellectual Property Theft and National Security: Agendas and Assumptions. The Information Society 32 (4): 256-268. https:// doi.org/10.1080/01972243.2016.1177762.

Hall, Peter. 1993. Policy Paradigms, Social Learning and the State. Comparative Politics 25 (2): 275-296. https://doi.org/10.2307/422246.

Kilic, Burcu, and Tamir Israel. 2015. The Highlights of the Trans-Pacific Partnership E-commerce Chapter. Public Citizen and the Samuelson-Glushko Canadian Internet Policy and Public Interest Clinic, November 5. http://www.citizen. org/documents/tpp-ecommerce-chapter-analysis.pdf.

Krugman, Paul. 2013a. TPP and IP, a Brief Note. New York Times (blog), December 14. http://krugman.blogs.nytimes.com/2013/12/14/tpp-andip-a-brief-note/.

- 2013b. TPP. New York Times (blog), December 12. http://krugman. blogs.nytimes.com/2013/12/12/tpp/.

- 2015a. The Mis-Selling of the TPP. New York Times (blog), May 19. http://krugman.blogs.nytimes.com/2015/05/19/the-mis-selling-of-tpp/.

- 2015b. This Is Not a Trade Agreement. New York Times (blog), April 26. http://krugman.blogs.nytimes.com/2015/04/26/this-is-not-a-tradeagreement/.

- 2015c. TPP at the NABE. New York Times (blog), March 11. http:// krugman.blogs.nytimes.com/2015/03/11/tpp-at-the-nabe/.

Langley, Paul. 2009. Power-Knowledge Estranged: From Susan Strange to Poststructuralism in British IPE. In Routledge Handbook of International Political Economy (IPE): IPE as a Global Conversation, ed. Mark Blyth, 126-139. New York: Routledge.

Litman, Jessica. 1990. The Public Domain. Emory Law Journal 39: 965-1023. https://www.law.duke.edu/pd/papers/litman_background.pdf.

Malcolm, Jeremy. 2015. The Final Leaked 'Secret' TPP Text Is All That We Feared: Top Down Control of the Internet. Global Research, October 12. http://www.globalresearch.ca/the-final-leaked-secret-tpp-text-is-all-that-wefeared-top-down-control-of-the-internet/5481702.

May, Christopher. 1996. Strange Fruit: Susan Strange's Theory of Structural Power in the International Political Economy. Global Society 10: 167-189. https://doi.org/10.1080/13600829608443105.

Mayer-Schönberger, Viktor, and Kenneth Cukier. 2013. Big Data: A Revolution That Will Transform How We Live, Work and Think. London: John Murray. 
Monga, Vipal. 2016. Accounting's 21st Century Challenge: How to Value Intangible Assets. Wall Street Journal, March 21. https://www.wsj.com/ articles/accountings-21st-century-challenge-how-to-value-intangible-assets1458605126.

Noble, Safiya Umoja. 2018. Algorithms of Oppression: How Search Engines Reinforce Racism. New York: University Press.

Ocean Tomo. 2015. Annual Study of Intangible Asset Market Value. March 5. www.oceantomo.com/2015/03/04/2015-intangible-asset-marketvalue-study.

Office of the United States Trade Representative. 2015. Summary of the TransPacific Partnership. Accessed November 16, 2016. https://ustr.gov/aboutus/policy-offices/press-office/press-releases/2015/october/summary-transpacific-partnership.

Polanyi, Karl. 2001. The Great Transformation: The Political and Economic Origins of Our Time. Boston: Beacon Press.

Powers, Shawn M., and Michael Jablonski. 2015. The Real Cyber War: The Political Economy of Internet Freedom. Chicago: University of Illinois Press.

Rodrik, Dani. 2011. The Globalisation Paradox: Democracy and the Future of the World Economy. New York: W.W. Norton \& Company.

Scassa, Teresa. 2017. Sharing Data in the Platform Economy: A Public Interest Argument for Access to Platform Data. UBC Law Review 50 (4): 1017-1071. https://papers.ssrn.com/sol3/papers.cfm?abstract_id=3077996.

Schneier, Bruce. 2015. Data and Goliath: The Hidden Battles to Collect Your Data and Control Your World. New York: W.W. Norton \& Company.

Scott, James. 1998. Seeing Like a State: How Certain Schemes to Improve the Human Condition Have Failed. New Haven: Yale University Press.

Sell, Susan K. 2003. Private Power, Public Law: The Globalisation of Intellectual Property Rights. Cambridge: Cambridge University Press.

Sherman, Brad, and Lionel Bently. 1999. The Making of Modern Intellectual Property Law. Cambridge: Cambridge University Press.

Solis, Mireya. 2015. The Geopolitical Importance of the Trans-Pacific Partnership: At Stake, a Liberal Economic Order. Order from Chaos blog, Brookings Institution, March 13. http://www.brookings.edu/blogs/order-from-chaos/ posts /2015/03/13-geopolitical-importance-transpacific-partnership.

Srnicek, Nick. 2017. Platform Capitalism. Cambridge: Polity.

Strange, Susan. 1986. Casino Capitalism. Oxford: Basil Blackwell.

- 1994. States and Markets. 2nd ed. New York: Continuum.

- 1998. Mad Money. Manchester: Manchester University Press.

Tooze, Roger. 2000. Susan Strange, Academic International Relations and the Study of International Political Economy. New Political Economy 5 (2): 280-289. https://doi.org/10.1080/713687770. 
Weatherall, Kimberlee. 2016. Intellectual Property in the TPP: Is Chapter 18 the New TRIPS? http://law.unimelb.edu.au/_data/assets/pdf_file/ 0009/1954152/Weatherall,-IP-in-the-TPP-The-New-TRIPS.pdf.

West, Sarah Myers. 2017. Data Capitalism: Redefining the Logics of Surveillance and Privacy. Business \& Society 58: 1-22. https://doi.org/10.1177/ 0007650317718185.

White House. 2015. National Security Strategy of the United States of America. Accessed September 3, 2018. http://nssarchive.us/national-security-strategy$2015 /$.

World Trade Organisation. 2018. World Trade Report 2018: The Future of World Trade: How Digital Technologies Are Transforming Global Commerce. Accessed November 8, 2018. https://www.wto.org/english/res_e/publications_e/ wtrl8_e.htm.

Zuboff, Shoshana. 2015. Big Other: Surveillance Capitalism and the Prospects of an Information Civilization. Journal of Information Technology 30 (1): 75-89. https://doi.org/10.1057/jit.2015.5.

Open Access This chapter is distributed under the terms of the Creative Commons Attribution 4.0 International License (http://creativecommons.org/licenses/ by $/ 4.0 /$ ), which permits use, duplication, adaptation, distribution and reproduction in any medium or format, as long as you give appropriate credit to the original author(s) and the source, a link is provided to the Creative Commons licence and any changes made are indicated.

The images or other third party material in this chapter are included in the work's Creative Commons licence, unless indicated otherwise in the credit line; if such material is not included in the work's Creative Commons licence and the respective action is not permitted by statutory regulation, users will need to obtain permission from the license holder to duplicate, adapt or reproduce the material.

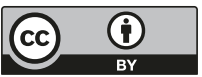

